\title{
A Review on Stone Columns used for Ground Improvement of Soft Soil
}

\author{
Istuti Singh ${ }^{1}$, Anil Kumar Sahu ${ }^{2}$ \\ ${ }^{1}$ Delhi Technological University \\ Bawana Road, Delhi, India \\ istutisingh_phd2k16@dtu.ac.in \\ ${ }^{2}$ Delhi Technological University \\ Bawana Road, Delhi, India \\ sahuanilkr@yahoo.co.in
}

\begin{abstract}
Stone columns repeatedly used for stabilization of soft soils. For the support of different structures, use of stone columns is increasing day by day. Stone columns are used for the improvement of settlement and bearing capacity of soft soils in reasonable fare and friendly towards the environment. In present paper, a review to analyse the behavior of stone columns used in different types of constructions such as oil storage tanks, embankments, buildings etc. The consequence of without encased and encased stone columns on several types of construction is studied. The effect of various diameters with various depths in ground also reviewed. For the encasement different types of geosynthetics are used for improvement of the results. For the prediction of the settlement of foundations reinforced with stone column number of numerical and physical approaches are done. This paper deals with several theories exist from past to present which helps in understanding the enhancements by stone columns in boosting soft soils. In development of geotechnical properties physical modelling has an important role.
\end{abstract}

Keywords: Stone column, Ground improvement, Geosynthetics, Soft soils.

\section{Introduction}

Ground improvement techniques are the techniques used to improve and alter poor ground conditions in order construction can meet project performance requirements in an economical way. The high cost of conventional foundations coupled with environmental concerns has made development of week soil deposits a necessity. Out of various techniques stone columns is trending technique for improving the weak strata. Based on past experiences the stone column design is still empirical and always needs field trials before execution.

Stone columns are significant in soil stabilization and are ideally welcome for improvement of soft clays, silts and loose silty sands. They provide a cost effective method for ground improvement. As India is a developing country, it requires more land for infrastructure development. For construction the availability of land is depleting, hence it is necessary to develop soil of low shearing strength, bearing capacity and high compressibility. Stone columns work more effectively in large area of stabilization of soil mass. On the load application column rapidly drains the excessive pore water pressure originated. Stone columns behaved as rigid element to carry higher shear stresses to reduce settlement, and improving the deformability and strength properties of soft soil. Stone column techniques are proved successful in improvement of stability of slopes, increasing the bearing capacity, reducing the differential and total settlements, reducing liquefaction property of sands and increasing the settlement time. This method was initiated in France in 1830's and is widely used especially in Europe since 1950's. The column consists of compacted pebbles or crushed stones compacted by a shaker.

The objective of this paper is to review the studies from past to present done on the stone columns used for the ground reinforcement.

Hughes et al., (1975) predicted the load settlement relationship of an single stone column in soft clay for plate loading. Vibro replacement method is used for column construction. The paramount column load depends on angle of friction generally used to cast column, size of the column and restraint of clay on the uncemented gravel. The load settlement curve for the clay is predicted by the stress strain data was obtained from a Cambridge pressure meter. The prediction is excellent, if the load delivers from the column to clay through side shear with correct column size. For the estimation of ultimate load 
and settlement characteristics the important factor is estimation of accurate column diameter. The bearing capacity of the natural soil is improved. Gneil and Bouazza, (2009) analysed the geogrid encased columns behavior by small scale model column test undertaken. The tests focus on investigating the partially encased columns behaviour with geogrid to a fully encased column by varying the encasement length. For both isolated and group columns the outcome of partly encased column specified a firmly lowering in upright strain with enrich length of the encasement. Bulging failure was discovered directly below the encasement. A impressive increment in stiffness followed by depletion in column strain obtained for completely encased columns, with $80 \%$ strain reduction

Keykhosropur, (2012) studied the effect of varying the length of encasement by a 3D numerical approach on groups. The determination of settlement and lateral deformations are compared with a group of fully encased columns. Through modelling the GECs behavior calibrated used in reclamation of field on project in Hmburg, Germany. To scrutinize the effects such as geosynthetic encasement stiffness, diameter of column, elasticity modulus and angle of friction, column stuff on the overall characteristics of GEC group carried out. To provide an optimal design the outer columns encasement is sufficient. For the internal angle of friction of column stuff the performance of GEC's is less sensitive. On the group behavior the elasticity modulus of the column stuff has less effect. Ali et. al., (2012) performed the model test on different depths of stone column i.e. short, floating and fully penetrated column with and without reinforcement. Due to several configurations and reinforcements used, reveals a subtle difference of the column appearance in failure mode. They concluded that providing the encasement is the ideal way for end bearing columns while there is not much variation for floating columns on the horizontal strip reinforcement and encasement showed. The stone column was installed at the centre of large tank and the footing load applied via sand mat in a controlled temperature and humidity. They analysed that the floating or end bearing (reinforced or unreinforced) stone columns always failed by bulging while short columns fail by punching. In end bearing stone columns geogrid gives more improved results as compared to geotextile for the couple of reinforcement while in floating columns geogrid is superior as the levelled strip however geotextile as the encasement. Elsawy, (2013) analyzed numerically the behavior of complete reinforced and unreinforced clay and geogrid encased stone columns beneath embankement loading. To investigate behavior of the clay, consolidation analysis is applied. The excess pore water pressure reduction of the foundation increases thus bearing capacity also increases. More improvement takes place in encased stone columns. Also analyze that the stress concentration generated contributes significantly in stone columns to the acceleration of soil consolidation. Indraratna, (2013) adopted the free strain behavior and considered clogging, arching by finite difference method to analyse soft soil embankment braced with stone column. The model presented is demonstrated by differentiating the existing models and field data to specify accuracy of the solutions.

Ali K et. al. (2014) analysed the failure stress on long floating and end bearing single and group of columns with and without reinforcement and due to several type of reinforcement. The exhumed deformed column shapes are used to fine the failure pattern used for different types of reinforcement. It was conclude that for end bearing columns geogrid was best type reinforcement. Geogrid and geotextile for horizontal reinforcement and encasement for floating columns were equally good. Almeida et. al., (2015) analysed the instrumentation and behavior result for embankment tested for soft soil by using geotextile encased granular columns with the total applied embankment stress approx $150 \mathrm{kPa}$ having $5.35 \mathrm{~m}$ height tested. The construction of embankment carried out in 4 stages in 65 days. The surplus pore pressure, settlements, surface perpendicular stress and radial distortion of the geotextile encasement were measured in soft soil and encasement. They studied differences in settlement and stress concentration between the upmost of the encased column and the soft soil. They concluded that by desirable pore water pressure, the differential settlement increases as embankment height increases. The vertical stress carried by the column was twice the stress imparted to the soft soil due to arching of soil. As the consolidation progressed, the vertical stress on the encased column improved.

Baruah and Sahu, (2016) compared the load versus settlement response with silty clay bed reinforced with stone column with different aggregate mixes, at different depth, with and without encasement. The plate load test was carried out in a large rectangular tank on a single column. He investigated by mixing different size of aggregates and by varying the size of aggregate in stone column. From the results obtained, load carrying capacity of silty clay bed improved and reduction in settlement. Hong et al., (2016) studied the effects of encasement strength and stiffness through model test on the individual geotextile wrapped granular column fixed in soft soil. The experimental values showed the bearing capacity of casted sand 
columns improved by wrapping even when rupture occurs. Sand columns wrapped with geotextiles of moderate to extreme stiffness marginal improvement is achieved. With low stiffness geotextile encasement, in the top 2.5D depth bulging of the wrapped sand column occurs whereas along the height of the column high stiffness geotextile encased sand columns exhibit uniform lateral deformation. By an analytical solution using cavity expansion theory, casted the bearing stresses of the encased columns. Mohapatra et al., (2017) analysed the three dimensional numerical analysis of geosynthetic encased granular column carried out in model and prototype scale by FLAC $^{3 \mathrm{D}}$ software. The soil is reinforced with two individual diameter of granular column i.e. $50 \mathrm{~mm}$ and $100 \mathrm{~mm}$ in three different arrangement patterns (single, triangular and square) in direct shear box to examine the effect of group confinement. At series of four various pressures i.e. 15, 30, 45 and $75 \mathrm{KPa}$ numerical simulations done. The results found that in geosynthetic encasement the tensile forces were mobilized in both vertical and circumferential directions. In granular column, this helps in mobilizing the additional confinement.

Cengiz and Guler, (2018) evaluated and compared the conventional and geosynthetic wrapped stone columns throughout seismic action placed in clay bed in a massive rectangular tank. To encourage the seismic behaviour of columns for embankment supports setup is placed on a large scale shaking table test (1-g model test) with surcharge loads applied. The water resistant strain gauges are used to measure strain throughout the experiment. Three different types of non woven geotextiles are used namely, TencatePolyfelt TS10 (deputed as GT1), Sefitec PP50 (GT2) and Stabilenka 100 (GT3) respectively. The extent of the seismically developed horizontal strains depends on stiffness of encasement. It is observed that gravel infilled stone columns lowered the settlement more efficiently than sand infill during earthquake. Geotextile wrapped stone columns showed supercilious results compared to conventional stone columns for both under static and seismic loading. Ghazavi et al., (2018) performed laboratory test on encased and horizontally encased stone columns (HRSCs) of 60, 80 and $100 \mathrm{~mm}$ diameters and $60 \mathrm{~mm}$ diameter in groups of stone column. The bearing capacity is increased while lateral bulging reduces by interlocking and frictional effects with infill aggregates. The optimum spacing across reinforcing sheets in HRSCs is $S_{r}=0.25 \mathrm{D}$. In case of vertically encased columns (VESCs), with the increase in diameter of columns encasement effect reduces vice versa in HRSCs. Numerically examined that with increasing horizontal layers and reducing spacing between layers bearing capacity increased.

\section{Codal provision for Settlement Computation}

There are various theories for the analysis of settlement is stone columns. In this the IS method (IS 15284 Part I, 2003) is discussed:

Settlement of ground treated maybe estimated by using the Reduced Stress Method on the basis of stress concentration factor ' $n$ ', the replacement ratio ' $a_{s}$ ', Settlement 's' of a stone column. Reinforced soil can be written as

$$
S=\beta \Delta \sigma m_{v} H
$$

Where $\mathrm{m}_{\mathrm{v}}=$ coefficient of volume compressibility

$$
\begin{gathered}
\beta=\text { settlement reduction ratio }=\underline{\text { Settlement of treated soil, } \mathrm{S}_{\mathrm{t}}} \\
\quad \beta=\frac{\mathbf{1}}{\text { Settlement of untreated soil, } \mathrm{S}} \\
\mathrm{n}=\text { stress concentration ratio }=\frac{\sigma \mathrm{s}}{\sigma \mathrm{g}}
\end{gathered}
$$

$\sigma_{\mathrm{s}}=$ vertical stress in compacted columns

$\sigma_{\mathrm{g}}=$ vertical stress in surrounding ground 


$$
\begin{gathered}
\sigma_{\mathrm{g}}=\frac{\boldsymbol{\sigma}}{\mathbf{1 + ( \mathbf { n } - \mathbf { 1 } ) \mathbf { a s }}} \\
\sigma_{\mathrm{s}}=\frac{\mathbf{n \sigma})^{1+(\mathbf{n}-\mathbf{1}) \mathbf{a s}}}{\mathrm{a}_{\mathrm{s}}=\text { Replacement ratio }=\frac{\mathbf{A s}}{\mathbf{A s}+\mathbf{A g}}}
\end{gathered}
$$

$\mathrm{A}_{\mathrm{S}}=$ area of the stone column

$\mathrm{A}_{\mathrm{g}}=$ area of ground surrounding the column

\section{Conclusion}

The reviewed literature concluded about the stone columns and the use of geosynthetics used for the encasement of stone columns experimentally and numerically. By providing encasement it gives more improved results. The stone columns designed are of types short, floating and fully penetrated. In short stone columns punching failure occurred while in fully penetrated stone columns bulging failure takes place. As now a days to fulfil the requirement of land more research is required in the field of construction of stone columns by using different types of geosynthetics according to the availability. The stone columns are constructed single or in groups depending upon the requirement. In group it maybe in triangular or in square pattern based on loading criterion. By using different type of factors according to the location different types of researches takes place to improve the properties of the soft soil. More research is to be required for the same.

\section{Acknowledgements}

I would like to pay my sincere gratitude to my supervisor Dr. A. K. Sahu, Professor of Civil Engineering Department for providing liberal guidance and sparing discussion time. I admire and acknowledge the kindness and infinite patience shown in all matters. I reveal my sincere thanks to Dr. Nirendra Dev, Professor and Head, Department of Civil Engineering. I also want to thanks to our parent institution for providing financial assistance.

\section{References}

[1] K. Ali, J. T. Shahu, and K. G. Sharma, "Model tests on geosynthetic reinforced stone columns: A comparative study," Geosynth. Int., vol. 19, no. 4, pp. 292-305, 2012.

[2] K. Ali, J. T. Shahu, and K. G. Sharma, "Model tests on single and group of stone columns with different geosynthetic reinforcement arrangement," Geosynth. Int., vol. 21, no. 2, pp. 103-118, 2014.

[3] M. Almeida, I. Hosseinpous, M. Riccio, and D. Alexiew, "Behaviour of geotextile encased granular columns supporting test embankment on soft deposit," ASCE Geotech. Geoenviron. Eng., vol. 141, no. 3, 2015.

[4] D. Baruah and A. K. Sahu, "Comparative study of load deformation behavior of silty clay bed reinforced with stone column of different depth and gradation," in Proceedings of International Conference on Engineering Geology in the New Millennium: Journal of Engineering Geology, New Delhi, 2015, pp. 822-830.

[5] C. Cengiz, and E. Guler, "Seismic behavior of geosynthetic encased columns and ordinary stone columns," Geotext. Geomembr., vol. 46, pp. 40-51, 2018.

[6] M. B. D. Elsawy, "Behaviour of soft ground improved by conventional and geogrid encased stone columns, based on FEM study," Geosynth. Int., vol. 20, no. 4, pp. 276-285, 2013.

[7] J. Gniel and A. Bouazza, "Improvement of soft soils using geogrid encased stone columns," Geotext. Geomembr., vol. 27, pp. 167-175, 2009.

[8] M. Ghazvi, A. E. Yamchi, and J. N. Afshar, "Bearing capacity of horizontally layered geosynthetic reinforced stone columns," Geotext. Geomembr., vol. 46, pp. 312-318, 2018.

[9] Y. S. Hong, C. S. Wu, and Y. S. Yu, "Model test on geotextile encased granular columns under 1-g and undrained conditions," Geotext. Geomembr., vol. 44, no. 1, pp. 13-27, 2016. 
[10] J. M. O. Hughes, N. J. Withers, and D. A. Greenwood, "Field trial of the reinforcing effect of a stone column," Geotechniue, vol. 25, no. 1, pp. 31-44, 1975.

[11] B. Indraratna, S. Basack, and C. Rujikiatkamjorn, "Numerical solution of stone column-improved soft soil considering arching, clogging and smear effects," Geotech. Geoenviron. Eng., vol. 139, pp. 377-394, 2013.

[12] IS: 15284 (Part I): 2003, "Design and construction for ground improvement - Guidelines."

[13] L. Keykhosropur, A. Soroush, and R. Imam, "Numerical analysis of geosynthetic encased stone columns." Geotext. Geomembr., vol. 35, pp. 61-68, 2012.

[14] S. R. Mohapatra, K. Rajagopal, and J. Sharma, "3- Dimensional numerical modeling of geosynthetic encased granular columns," Geotext. Geomembr., vol. 45, pp. 131-141, 2017. 